\title{
Adaptation for Brazilian Portuguese of a scale to measure willingness to wear condoms
}

\section{Adaptação para o português de uma escala para medir intenção de utilizar preservativos}

\author{
Elisabeth Meyer ${ }^{\mathrm{a}}$, Adriana Carvalhal ${ }^{\mathrm{b}}$ and Flávio Pechansky

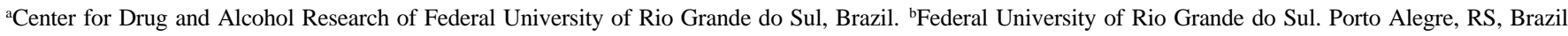

\begin{abstract}
Introduction: We describe the process of translation and adaptation into Brazilian Portuguese of the Stages of Change for Condom Use, developed at the University of Rhode Island, USA. The scale aims to evaluate the readiness to wear condoms based on the Stages of Change model. The goal of this study was to translate, perform the necessary adaptations and evaluate the applicability of the scale in Brazilian Portuguese.

Method: A first Portuguese version of the scale, complying with internationally accepted criteria for transcultural adaptation of instruments, was applied to 15 individuals who differed regarding their sociodemographic variables. Results: adjustments were needed in order to render the adaptation viable, what allowed to obtain the final version of the Stages of Change for Condom Use. Subjects of this sample demonstrated good acceptance and understanding of the items presented in the scale.

Conclusion: The utilization of the scale with individuals of different sociodemographic strata enabled the necessary adaptations to the Brazilian sociocultural reality and to the level of understanding of ordinary individuals.
\end{abstract}

Keywords HIV/AIDS. Condom. Stages of change. Scales.

Resumo Introdução: Descrevemos o processo de tradução e adaptação para a língua portuguesa da "Stages of Change for Condom Use Scale" - Escala Estágios de Mudança para o Uso do Preservativo - desenvolvida na Universidade de Rhode Island, EUA. A escala tem como foco avaliar a prontidão para o uso de preservativos baseado nos estágios de mudança. O objetivo foi traduzir, realizar as adaptações necessárias e avaliar a aplicabilidade da escala em português.

Método: Uma primeira versão em português da escala, seguindo os critérios internacionalmente aceitos para adaptação transcultural de instrumentos, foi aplicada em 15 indivíduos que se diferenciavam quanto às variáveis sociodemográficas.

Resultados: Houve necessidade de ajustes para viabilizar a adaptação, o que permitiu a obtenção da versão final da escala Estágios de Mudança para o Uso do Preservativo. Os sujeitos desta amostra demonstraram boa aceitação e compreensão dos itens apresentados através da escala.

Conclusão: A utilização da escala com indivíduos de diferentes extratos sociodemográficos possibilitou fazer as necessárias adequações à realidade sociocultural brasileira e ao nível de compreensão de qualquer pessoa.

Descritores HIV/Aids. Preservativos. Estágios de mudança. Escalas.

\section{Introduction}

With the increasing incidence of the HIV infection in the world, many efforts have been made to implement and improve preventive actions aiming at changes in risky behaviors, having the target of reducing their seroincidence rates.

Many healthcare providers would like to understand why the same therapeutic approach is effective with some patients, while with others it ends being partially, or even completely, fruitless. For different reasons many patients do not improve or, as the worst outcome, even withdraw their treatment. It is known that there is a set of factors that will directly influence treatment, such as the understanding that changes have to be ac- 
complished, the level of psychological distress, the willingness to make changes, the level of compliance with the treatment, and social and financial aspects, among others.

Based on studies on how people withdraw from smoking by them selves, ${ }^{1-4}$ researchers of the University of Rhode Island (USA) developed the Model of Stages of Change. According to this research group, the process of behavioral change takes place through five stages, in a continuum: precontemplation, contemplation, preparation, action and maintenance. Examples of these stages can be seen in Table.

The recent literature has shown and recommended efforts toward studies fostering a better evaluation of the stages of change and the development of procedures aiming to identify the specific stage that every individual is at a certain point. ${ }^{5}$ There have been also further studies whose common focus is on health-related behavioral changes - such as withdrawing smoking, following exercise programs, sun protection, reduction in dietary fat intake, weight control, safe sex, use of condoms, compliance with mammography control, compliance with medication, stress management and stopping drug abuse, among others. ${ }^{6-12}$ These studies have helped to understand how individuals change their behavior as well as the resulting development of specific, focal approaches, according to the patient's stage and his/her willingness to change.

Changes of attitude and behavior and the Acquired Immunodeficiency Syndrome (AIDS) are directly related. The epidemiological data provided by the World Health Organization (WHO) and the Brazilian Health Department ${ }^{13}$ allow us to observe that the change of risk behaviors, such as preventing HIV infection, is not easy to take place. With regard to the exposure category, sexual transmission comprises $54.2 \%$ of the notified cases between 1980-2001 (heterosexual exposure accounts for $27.4 \%$; homosexual 17\%, and bisexual 9.7\%). A tendency towards reduction is noteworthy regarding the incidence rate among homosexuals, who had accounted for $30.3 \%$ of the overall prevalence in the first decade of the infection, and in 2001 accounted for only $10 \%$ of the cases. On the other hand, heterosexuals had accounted for $10.4 \%$ in the first decade, and in 2001 had $52 \%$ prevalence, suggesting a migration of the most frequent infection mode from unprotected homosexual sex to unprotected heterosexual sex.

Even if the Brazilian population were reasonably informed about the disease, that would not be enough to persuade people to change their behavior, although the use of male and female condoms during sex has been identified as an important barrier method for the prevention of transmission of HIV and other

Table - stages of change.

\begin{tabular}{ll}
\hline Stages of change & Characterization of the stage \\
\hline $\begin{array}{l}\text { Precontemplation } \\
\text { Contemplation }\end{array}$ & $\begin{array}{l}\text { No intention to start changes for the next } 6 \text { months } \\
\text { Intends to start changes in the next } 6 \text { months } \\
\text { Preparation }\end{array}$ \\
$\begin{array}{l}\text { Intends to start changes in the next thirty days } \\
\text { Therion }\end{array}$ & $\begin{array}{l}\text { There have been overt behavioral changes in the past } \\
\text { Maintenance }\end{array}$ \\
& $\begin{array}{l}\text { There have been behavioral changes for more than } 6 \\
\text { months }\end{array}$ \\
\hline
\end{tabular}

sexually-transmitted diseases, and it can make the difference between getting infected or not.

With the goal of evaluating the stages of change for condom use, researchers of the University of Rhode Island (USA) developed the Stages of Change for Condom Use. ${ }^{14}$ This scale is self-applicable, anonymous, and takes only two minutes to be completed. It comprises seven questions related to the use of condoms, and the included items focus on the different stages of change.

The adoption of the Stages of Change Model and the different instruments developed by the Rhode Island researchers is an already-validated procedure in the scientific literature and it is applied in different parts of the world. Its use remains a fruitful open ground for research and development, aiming at improving and broadening its clinical applications.

The utilization of the Brazilian version of the Stages of Change for Condom Use will allow the observation of the stages of change for condom use in each individual, leading us to structure and adapt the best therapeutic approach for every stage. Moreover, the utilization of the Stages of Change for Condom Use will enable us to compare studies conducted in Brazil with findings of international studies.

The goal of this preliminary study is to present the development of the Brazilian Portuguese version for the evaluation instrument of the stages of change with regard to readiness to wear condoms.

\section{Method}

Following the authorization given by the U.S. researcher,* the scale was translated into Portuguese. The translation of the scale was simultaneously performed by this paper's authors and a professional translator, experienced in the translation of medical questionnaires and instruments. Next, the two versions were compared, resulting in a preliminary Brazilian version. This version was applied to 15 individuals of the community with substantial sociocultural differences, with the main goal of verifying the understanding of the questions by individuals from different cultural and socioeconomic strata, and collecting suggestions for potential changes. The sample was intentional, and the selection of individuals was based on their educational background. A key characteristic of the intentional sampling, or sampling by judgment, is that population subjects are selected considering whether the sample will be able to offer the requested contributions. The authors used their judgment to select and to invite, personally, those members of the population that would be good sources of information and would also contribute to the verification and to the necessary adjustments. Interviewees responded to the scale after having been informed about the study's objectives, being assured their privacy, and were offered the option to decline or refuse to participate in the research. As the outcome of interest of the scale is based on highly private aspects, or related to sexuality, participants were informed that they have not necessarily to answer to the questions. This limited the focus of discussion to understand only the presented items and materials. 


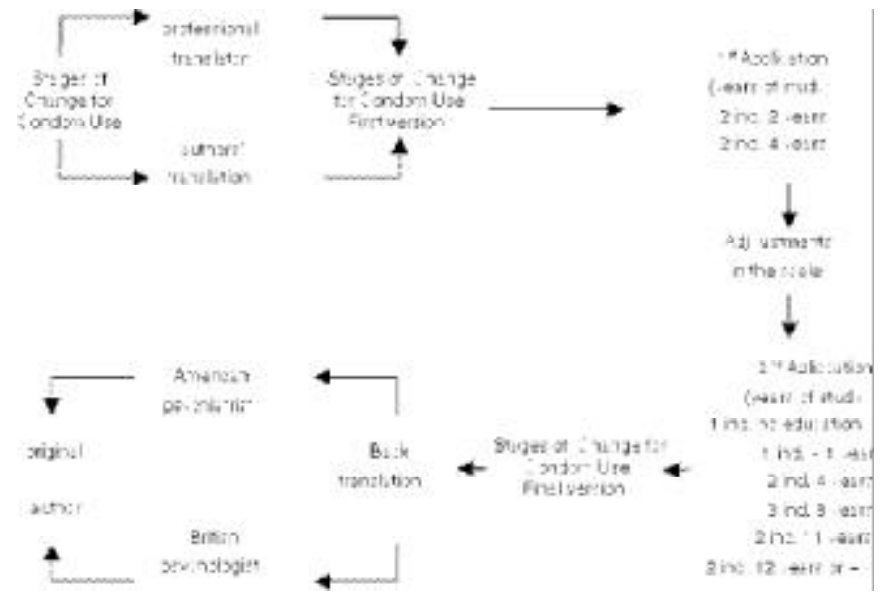

Figure - Methodological steps in the transcultural adaptation of the scale Stages of Change for Condom Use.

Of the 15 volunteers, seven were male and eight female, with ages ranging from 16 to 67 years. Subjects had different educational levels, ranging from 'no education' to 'above 12 years of study'.

The scale was applied in two stages in order to better finetune the instrument. Four individuals participated in the first application, two of these had two schooling years, while the other two had studied for four years, what enabled the first adjustments in the scale. At the second stage, the already-modified scale was applied to the other individuals.

The main goal in the translation and adaptation was to maintain the clarity, objectivity and simpleness of the questions. ${ }^{15}$ In this process, we found that a simpler language had to be chosen, and some expressions were modified, which rendered the understanding of the tool easier. ${ }^{16}$ An example of adaptation is demonstrated by the reformulation of the item 'condom', to which the Portuguese word 'camisinha' was added from that point onwards. Another concern was to observe whether the scale items took Brazilian use of language and culture into account. ${ }^{17}$

The scale was applied at the abode of the individuals participating in the sample; only the interviewer and the interviewee were present. The process lasted for approximately 20 minutes. At first, the questions were formulated by the interviewer, and should the question or a particular word not be understood, it was reformulated together with the interviewee until they could grasp its real meaning. Of paramount importance was putting the translated version to test with individuals of little schooling, for the purpose of examining the understanding of the questions. ${ }^{18}$ All ideas proposed by the interviewees were observed, and the necessary adjustments were accomplished. The cycle scale application-adaptations-new application was concluded when the authors had observed that volunteers had a total understanding of the questions. The scale does not have one total score, its focus is rather the assessment on the readiness for using condoms based on stages of change. The scale functions in five dimensions, punctuating each of them individually and indicating at which stage the subject presently is.

Once the scale was considered useful for utilization in Portu- guese, the process of translating it back to English took place. The back translation was performed by an American psychiatrist and a British psychologist living in Brazil at that time, who had no contact with the original scale whatsoever. ${ }^{18}$ The two resulting versions ${ }^{19}$ were sent to the original author of the scale. The original author has not pointed out to differences between the original scale and the versions which were translated back.

Currently, a statistical study on the psychometric qualities of the scale is being conducted. A detailed description of the results will be addressed in a new article. The steps taken in the process of adapting the scale up to this point are shown in Figure.

\section{Discussion}

The translation and adaptation process of an instrument to be used in another culture takes into account a diversity of elements and demands a careful methodology. Several authors ${ }^{15,17,19,20}$ strongly recommend that the scales used in cultures other than that of the original version undergo an accurate process of translation, transcultural adaptation and validation. In the course of the transcultural adaptation of the Stages of Change for Condom Use, an effort was made to achieve maximal correspondence between the original scale and the translated one. The process of converting a language into another must chiefly focus on potential language distortions, prioritizing the pursuit of a cultural approximation. The methodological criteria recommended by $\mathrm{WHO}^{15}$ and different authors ${ }^{16-19}$ have facilitated the accomplishment of such a process. Total approval of the translation back to English by the original scale's author supports the accuracy of the methodology employed.

The application of the scale to individuals of the community enabled us to perform the necessary adaptations to Brazilian sociocultural reality and to the level of understanding of ordinary individuals. Difficulties related to the reading and understanding of some scale items were found in the application to less educated subjects, which entailed the choice of words and expressions known by individuals of limited vocabulary.

The quick self-applicable format allows a great number of individuals to be easily tested. We must highlight that, as it is a self-answered instrument, uneducated individuals will need help to read the questionnaire, and it is not possible to predict whether at this stage of evaluation the scale will unveil different results from literate individuals or not.

The use of the Stages of Change for Condom Use, by identifying the stages of change for condom use, will enable ours and other research groups in the field to structure and fit the best therapeutic approach for each individual stage. In addition, the utilization of the Stages of Change for Condom Use will enable the comparison of researches accomplished in Brazil with findings from international studies. The existence of a Brazilian Portuguese version of the scale will render the access to the tool easy, encouraging other researchers to use it.

\section{Acknowledgments}

The authors express their esteem to Dr. Robin Clein and Shoshana Sokoloff for translating back the scale. 


\section{Escala estágios de mudança para o uso de preservativo}

\section{Lembre-se, sexo é aqui definido como somente sexo vaginal ou anal (não considere sexo oral ou outro tipo de sexo).}

1. Você teve relações sexuais com alguém durante os últimos 30 dias ou 2 meses?

(1) Eu tive relações sexuais nos últimos 30 dias (para as questões 2-5 circule 30 dias).

(2) Eu tive relações sexuais nos últimos 2 meses, mas não nos últimos 30 dias (para as questões 2-5 circule 2 meses).

(3) Não, eu não tive relações sexuais durante os últimos 2 meses (então, pule as questões 2-5).

2. Com quantos parceiros você teve relações sexuais nos últimos (30 dias ou 2 meses)?

3. Quantas vezes nos últimos (30 dias ou 2 meses) você teve relações sexuais?

4. Quantas vezes nos últimos (30 dias ou 2 meses) você usou preservativo (camisinha) quando teve relações sexuais?

5. Quando você teve relações sexuais nos últimos (30 dias ou

2 meses), com que freqüência usou preservativa (camisinha)?
(1) sempre
(2) quase todas às vezes
(3) algumas vezes
(4) quase nunca
(5) nunca

\section{References}

1. Prochaska JO, DiClemente C. Transtheoretical therapy: toward a more integrative model of change. Psychotherapy: Theory Res Practice 1982;19(3):276-88

2. Prochaska JO, DiClemente C. Stages and processes of self-change of smoking: toward an integrative model of change. J Consult Clin Psychol 1983;51(3):390-5.

3. Prochaska JO, DiClementi CC, Vellicer WF, Ginpil S, Norcross JC. Predicting change in smoking status for self-changers. Addict Behav 1985;10(4):395-406.

4. Laranjeira R, Gigliotti A. Tratamento da dependência da nicotina. Psiquiatr Prática Méd 2000;33(2):9-16.

5. Institute of Medicine (US). Division of Neuroscience and Behavioral Health. Committee on Opportunities on Drug Abuse Research. Pathways of addiction: opportunities in drug abuse research. Washington (DC): The Institute; 2000

6. Sutton S. Os "estágios de mudança" podem orientar o tratamento das adições? Um exame crítico do modelo de Prochaska e DiClemente. In: Edwards G, Dare C, editores. Psicoterapia e tratamento de adições. Porto Alegre: Artes Médicas; 1997. p. 173-88.

7. Sutton S. Back to the drawing board? A review of applications of the transtheoretical model to substance use. Addiction 2001;96(1):175-86.

8. Willoughby FW, Edens JF. Construct validity and predictive utility of the stages of change scale for alcoholics. J Subst Abuse 1996;8(3):275-91.

9. Redding CA, et al. Health behavior models. International Electronic Journal of Health Education [periódico online] 2000;3 (Special). Available in URL: http://www.iejhe.org

10. Prochaska JO, Velicer WF, Rossi JS, Goldstein MG, Marcus BH, Rakowski $\mathrm{W}$, et al. Stages of change and decisional balance for 12 problem behaviors. Health Psychol 1994;13(1):39-46.

11. Fischer JD, Fischer WA. Theoretical approaches to individual-level change in HIV-risk behavior. In: HIV prevention handbook; 2001. p. 3-55.

12. Willey C, Redding C, Stafford J, Garfield F, Geletko S, Flanigan T, et al. Stages of change for adherence with medication regimens for chronic disease: development and validation of a measure. Clin Ther 2000;22(7):858-71.
6. Você está pensando ou planeja usar preservativo (camisinha) em todas as relações sexuais?

(1) Não, eu não tenho pensado sobre usar.

(2) Sim, Eu tenho pensado a respeito de usar nos próximos 6 meses.

(3) Sim, eu tenho planejado usar nos próximos 30 dias.

(4) Eu já uso preservativo (camisinha) todo tempo.

7. Desde quando você usa preservativo (camisinha) o tempo todo, quando tem relações sexuais?

(1) Eu não tenho usado preservativo todo tempo.

(2) 1-3 meses.

(3) 4-6 meses.

(4) 7-11 meses.

(5) 1 ano ou mais.

\begin{tabular}{ccccccc}
\hline Item & PC & C & PR & A & $M$ & \\
\hline 5 & $2-5$ & $2-5$ & $3-5$ & 2 & 1 & 1 \\
6 & 1 & 2 & 3 & 3 & - & - \\
7 & - & - & - & - & $2-3=$ menos de & $4-5=6$ meses \\
& & & & & ou meses mais \\
\hline
\end{tabular}

13. Ministério da Saúde do Brasil. Boletim Epidemiológico AIDS jan/mar 2001. Available in URL: http:// www. aids.gov.br

14. Brown-Peterside P, Redding CA, Ren L, Koblin BA. Acceptability of a stage-matched expert system intervention to increase condom use among women at high risk of HIV infection in New York City. AIDS Educ Prev 2000;12(2):171-81.

15. Fleck M, et al. Desenvolvimento da versão em português do instrumento de avaliação de qualidade de vida da OMS (WHOQOL-100). Rev Bras Psiquiatr 1999;21(1):19-28.

16. Rosa M, Marcolin M. Tradução e adaptação da escala de Influências Medicamentosas (ROMI): um instrumento para avaliar a aderência ao tratamento. J Bras Psiquiatr 2000;49(10-12):405-9.

17. Cardoso CS, et al. Escala de qualidade de vida para pacientes com esquizofrenia (QLS-BR): adaptação transcultural para o Brasil. J Bras Psiquiatr 2002;51(1):31-8

18. Jorge MR. Adaptação transcultural de instrumentos de pesquisa em saúde mental. Rev Psiq Clin 1998;25(5):233-9.

19. Caron J. Un guide de validation transculturelle dês instruments de mesure em santé mentale. Available in URL:http:// www.rsmq.qc.ca/fr/ instruments/guide.htm

20. Ballester D, et al. Epidemiologia psiquiátrica: análise crítica dos instrumentos de avaliação em psiquiatria. Rev Psiquiatr RGS 2000;22(2):115-20.

\section{Correspondence:}

Elisabeth Meyer

Alameda Major Francisco Barcelos, 88

91340-390 Porto Alegre, RS, Brazil

E-mail: to_bethmeyer@hotmail.com 